\title{
RELATIVISTIC THERMAL RE-EMISSION MODEL
}

\author{
Jânia Duha ${ }^{1}$, Germano B. Afonso ${ }^{1}$ \& Luiz D. D. Ferreira ${ }^{2}$
}

Received November 30, 2001 / Accepted January 15, 2003

\begin{abstract}
All bodies in the universe are constantly absorbing heat from surrounding thermal sources. This heat will be reemitted after a time lag. The temperature at each point of the heated surface will determine the frequency $n$ of the photons sent out in such way that the total momentum associated to this process of energy loss depends on how the temperature is distributed at the surface. If the total momentum is not null, a thermal force will be produced whose intensity and direction will depend, fundamentally, on the temperature distribution at the surface: points with high temperature will re-emit photons with high frequencies and vice-versa. High frequency implies a great loss of momentum in the emission direction, and consequently great re-emission force in the opposite direction. But, not only the temperature can determine the frequency of the photons sent out but also the state at rest or movement of the body. When it presents some kind of movement (rotation, translation, etc.), the Doppler effect will change the frequencies of these photons and the frequency $v$ must be replaced by $v^{\prime}$. As a consequence, the resulting force will change too. In this work, we model the temperature variation (frequency variation) due to the Doppler effect and apply the new temperature distribution in the thermal re-emission model. The total force obtained by this "relativistic" thermal re-emission model has two terms: 1) the standard thermal re-emission force (without Doppler considerations) and 2) the relativistic correction of this force, similar to the standard Poynting-Robertson force. The thermal re-emission model presented here indicates that, in general, most of the several disturbing forces can be unified, providing a new and simple view for the understanding of the entire physics involved in such phenomena.
\end{abstract}

Key words: Thermal re-emission; Poynting-Robertson; Doppler; Unified model; Non-gravitational effects.

MODELO RELATIVÍSTICO DE RE-EMISSÃO TÉRMICA - Todos os corpos no universo estão constantemente absorvendo calor das fontes de energia térmica ao seu redor. Este calor, após um certo lapso de tempo, será re-emitido. A temperatura de cada ponto na superficie aquecida irá determinar a freqüência n dos fótons re-emitidos, de tal forma que o momentum total relacionado à este processo de perda de energia depende de como a temperatura está distribuída na superficie. Se o momentum resultante não é nulo, surgirá uma força térmica cujas direção e intensidade irão depender, fundamentalmente, dessa distribuição de temperaturas na superfície: pontos com temperatura alta irão re-emitir fótons com altas freqüências e vice-versa. Freqüência alta implica em uma grande perda de momentum na direção de emissão, e conseqüentemente, uma grande força de re-emissão na direção oposta. Não é apenas a temperatura que pode determinar a freqüencia dos fótons emitidos mas, também, o estado de repouso ou movimento do corpo. Quando este apresenta algum tipo de movimento (rotação, translação, etc.) o efeito Doppler irá alterar as freqüências destes fótons e a freqüência $v$ deverá ser substituida por v'. Como conseqüência, a força resultante será alterada, também. Neste trabalho, a variação da temperatura (variação de freqüência) devida ao efeito Doppler é modelada e a nova distribuição de temperaturas é aplicada ao modelo de re-emissão térmica. A força total obtida por este modelo "relativístico" de re-emissão térmica possui dois termos: 1) a força de re-emissão térmica padrão (sem considerações Doppler, e 2) a correção relativística a esta força que é semelhante à força PoyntingRobertson padrão. O modelo de re-emissão térmica, apresentado aqui demonstra que, de forma geral, a maioria das forças de perturbação pode ser unificada, conduzindo a um ponto de vista novo e simples, capaz de prover a compreensão de toda a física envolvida em fenômenos deste tipo.

Palavras-chave: Re-emissão térmica; Poynting-Robertson; Doppler; Modelo unificado; Efeitos nãogravitacionais. 


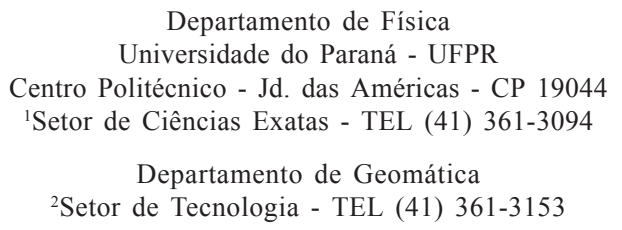

\section{INTRODUCTION}

To understand the relativistic thermal re-emission model we must present some basic concepts of the following effects: Thermal Re-emission, Doppler and Poynting-Robertson. These effects are closely related and one of the most important purposes of this work is to show how this happens.

The thermal re-emission effect appears every time when a particle, with anisotropy in its superficial temperature distribution, re-emits thermal radiation. The frequencies of the re-emitted photons depend directly on the temperature, so the net loss of momentum is not null and a thermal force appears.

The Doppler effect is the apparent change in wavelength of sound or light caused by the motion of the source, observer or both. Waves emitted by a moving object as received by an observer will be blueshifted (compressed) if approaching, redshifted (elongated) if receding. It occurs both in sound and light. How much the frequencies change depends on how fast the object is moving toward or away from the receiver.

The third effect is called Poynting-Robertson(PR) and can be explained as follows: the Sun's rays that strike particles orbiting the Sun are partially reflected and partially absorbed. In the first case (reflection), the particles will tend to slow down (momentum conservation law). This is how it works: rain falling on a speeding car tends to strike the front of the car and slow it down slightly. Similarly, the Sun's rays that strike particles orbiting the Sun tend to slow them down, causing them to spiral into the Sun.

In the second case, the absorbed radiation will be re-emitted after a time lag (so, equal rates of absorption and re-emission, means mass conservation), but if the particles present some kind of movement in the Sun's referential system (translation and rotation) one must take into account that the outgoing photons will emerge with different frequencies due to the Doppler effect. Again, the net loss of momentum is not null and the particles will tend to slow down.

In general, reflection and absorption occurs simultaneously so the PR effect presents some level of complexity that cannot be ignored. But in the work presented here we will focus our attention only on the effects due to the re-emission of the absorbed radiation.

\section{STANDARD THERMAL RE-EMISSION MODEL}

In order to obtain the temperature distribution of the spherical surface, we solve the heat conduction equation with the appropriate boundary conditions (Afonso \& Foryta, 1989; Rubincam, 1990, 1997; Duha, 1996) according to the energy conservation law: the net loss of heat for the surface element is given by the difference between the thermal energy absorbed $(\alpha \mathrm{I})$ and the energy re-emitted $\left(\varepsilon \sigma \mathrm{T}^{4}\right)$, in the unit of area and time. Here $\alpha$ and $\varepsilon$ are the energy absorption and emission coefficients, respectively, at the body's surface and $\sigma$ is the Stefan-Boltzmann constant. Therefore the radiance I is related to the heat source and represents the incident radiant energy per unit of area and time. This radiance, $\mathrm{I}$, is associated with the body's surface temperature $T$. The radiance re-emitted by a spherical body surface is $\mathrm{I}_{\text {Sup }}=\varepsilon \sigma \mathrm{T}^{4}$, then the radiance estimate for a specific point at the surface is only possible through the knowledge of the temperature $\mathrm{T}$ at this point.

The surface temperature is $\mathrm{T}=\mathrm{T}_{0}+\Delta \mathrm{T}$, where $\mathrm{T}_{0}$ is the mean temperature and $\Delta \mathrm{T}$ is the temperature variation which has a periodic behavior. All area elements of the satellite surface re-emit radiation according to different temperature values. The reemitted thermal radiation (photons) carry away energy andmomentum. This momentum loss can be computed through the simple relation: momentum $=$ energy $/ c$, where $c$ is the speed of light, in such way that the total 
momentum loss along the normal direction at the surface element considered is:

$$
P=\frac{2 \varepsilon \sigma}{3 c} T^{4},
$$

and the force connected with this loss of momentum for a given point at the surface is:

$$
d \mathbf{F}=-\frac{2 \varepsilon \sigma}{3 c} T^{4} d \mathbf{A},
$$

where, $\mathrm{d} \mathbf{A}=\mathrm{d} A \mathbf{n}$ is the vector of the area element, in spherical coordinates, for the reference system $(x y z)$ according to Figure (1). The resulting thermal reemission force is obtained through the integration of the total force elements $d \mathrm{~F}$

$$
\mathbf{F}=-\frac{2 \varepsilon \sigma}{3 c} \int_{\mathbf{A}_{\text {sphere }}} T^{4} d A \mathbf{n}
$$

where $d A=R^{2} \sin \theta d \theta d \phi$ is the area element and $\mathbf{n}=\sin \theta \cos \phi \mathbf{i}+\sin \theta \sin \phi \mathbf{j}+\cos \theta \mathbf{k}$, the unit vector normal to the surface.

\section{FIGURE 1 - AREA ELEMENT IN SPHERICAL COORDINATES}

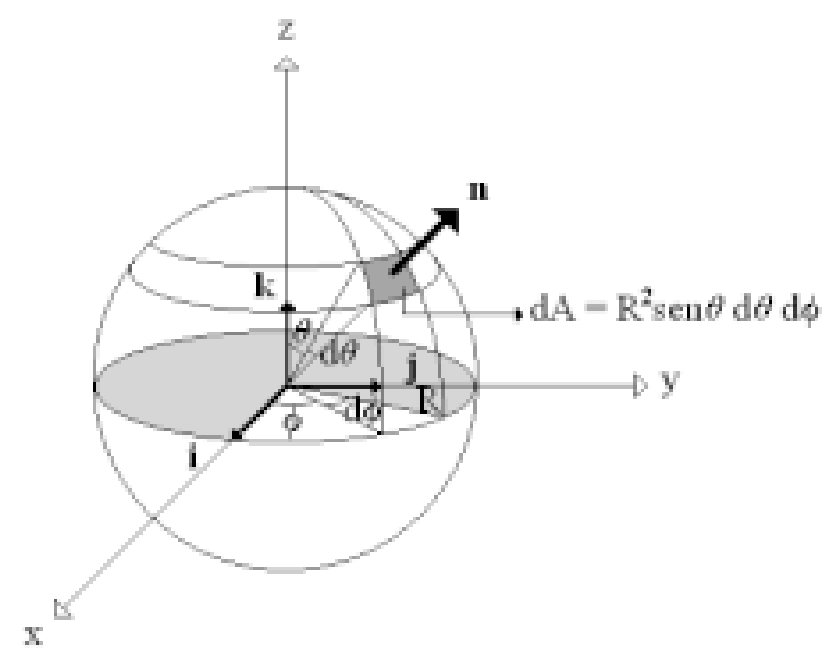

Figure 1 - Spherical coordinates of the area element in the coordinate system $(x y z)$ fixed for the spherical body.

Figura 1 - Coordenadas esféricas do elemento de área no sistema de coordenadas (xyz) fixo no corpo esférico.
Rewriting $T^{4}$ as a binomial expansion and assuming that $\Delta T \ll T_{0}$, we obtain the following approximated expression:

$$
T^{4}=T_{0}^{4}+4 T_{0}^{3} \Delta T
$$

Applying the relation above in the Eq. (3) one obtain:

$$
\mathbf{F}=-\frac{2 \varepsilon \sigma}{3 c} \int_{0}^{\pi} \int_{0}^{2 \pi}\left(T_{0}^{4}+4 T_{0}^{3} \Delta T\right) d A \mathbf{n}
$$

that, after integration, becomes:

$$
\begin{gathered}
\mathbf{F}=n_{f}\left\{A_{1} \sin \left(v_{2} t-\delta_{2}\right)\left[\cos \left(v_{1} t-\delta_{1}\right) \mathbf{i}+\sin \left(v_{1} t-\delta_{1}\right) \mathbf{j}\right]+\right. \\
\left.+A_{2} \cos \left(v_{2} t-\delta_{2}\right) \mathbf{k}\right\},
\end{gathered}
$$

where the two most important angular movements for the satellite rotation and translation (with angular frequencies, $v_{1}$ and $v_{2}$, respectively) are taken into account, in such manner that $\delta_{1}$ is the thermal lag angle due to rotation; $\delta_{2}$ is the thermal lag angle due to translation, and $\mathrm{A}_{1}$ and $\mathrm{A}_{2}$ are functions of the: absorption $(\alpha)$ and emission $(\varepsilon)$ coefficients, radius $(\mathrm{R})$, mean radiance $\left(\mathrm{I}_{0}\right)$, mean temperature $\left(\mathrm{T}_{0}\right)$, and angular frequencies $v_{1}$ and $v_{2}$.

The symbol $i$ is used to indicate when the quantities are computed with $v=v_{1}$ (day-night effect) and (summer-winter effect).

\section{RELATIVISTIC THERMAL RE-EMISSION MODEL}

The spectral radiance of a black body, $\mathrm{I}_{\mathrm{T}}(\mathrm{v})$, is defined through the energy emitted in the unit of time and area by a surface with absolute temperature $\mathrm{T}$, comprising radiation with frequencies at the interval $v$ to $v+\delta v$. There is, however, one specific frequency associated to a maximum radiance. The Wien law (Eisberg \& Resnick, 1986) shows that there is a wavelength, $\lambda_{\max }$ (or frequency $v_{\max }$ ) connected with 
maximum radiance and it is given by the following relation:

$$
\lambda_{\max } T=C_{\text {Ien }},
$$

where, $C_{\text {Ien }}=2.898 \times 10^{-3} \mathrm{mK}$ is the Wien constant. Note that the Eq. (7) can be rewritten as:

$$
T=C_{\text {Ien }} \frac{1}{\lambda_{\text {máx }}} .
$$

But, $\lambda v=c$, so:

$$
\frac{1}{\lambda}=\frac{v}{C},
$$

where we assume that $\nu$ and $\lambda$ are associated with maximum radiance, and so the Eq. (8) can be rewritten as:

$$
T=C_{1} v,
$$

where $C_{1}=C_{\text {Ien }} / c$ is constant.

A body heated up by a thermal energy source will re-emit photons with frequency $v$. However if, at some reference system, this body has velocity $V \neq 0$, then the frequency $v$ must be replaced by $v$ ' (Landau \& Lifchitz, 1966):

$$
v^{\prime}=v \frac{\sqrt{1-\frac{V^{2}}{c^{2}}}}{\left(1-\frac{V}{c} \cos \alpha\right)}
$$

where $\alpha$ is the angle between the directions of wave emission and body (source) movement.

According to the Eq. (10) the frequency $v^{\prime}$ is associated to a temperature $T^{\prime}$, and we can write:

$$
T^{\prime}=C_{1} v^{\prime}=C_{1} v\left(\frac{\sqrt{1-\frac{V^{2}}{c^{2}}}}{1-\frac{V}{c} \cos \alpha}\right)=T\left(\frac{\sqrt{1-\frac{V^{2}}{c^{2}}}}{1-\frac{V}{c} \cos \alpha}\right),
$$

and

$$
\left(T^{\prime}\right)^{4}=T^{4}\left(\frac{\sqrt{1-\frac{V^{2}}{c^{2}}}}{1-\frac{V}{c} \cos \alpha}\right)^{4}=T^{4} \frac{\left(1-\frac{V^{2}}{c^{2}}\right)^{2}}{\left(1-\frac{V}{c} \cos \alpha\right)^{4}}
$$

But, according to our thermal model we have assumed that $T^{4}=T_{0}^{4}+4 T_{0}^{3} \Delta T$ (Eq. (4)), then:

$$
\left(T^{\prime}\right)^{4}=\left(T_{0}^{4}+4 T_{0}^{3} \Delta T\right) \frac{\left(1-\frac{V^{2}}{c^{2}}\right)^{2}}{\left(1-\frac{V}{c} \cos \alpha\right)^{4}} .
$$

According to the binomial expansion, if $(V \cos \alpha) / c<<1$, we can expand the term in a series as follows:

$$
\left(a-\frac{V}{c} \cos \alpha\right)^{-4}=1+4\left(\frac{V}{c} \cos \alpha\right)+10\left(\frac{V}{c} \cos \alpha\right)^{2}+\ldots
$$

Using the relation above we can replace Eq. (14) by an approximated expression that takes into account only the two first terms of the expansion (15). So, the Eq. (14) can be rewritten as follows:

$$
\left(T^{\prime}\right)^{4}=\left(T_{0}^{4}+4 T_{0}^{3} \Delta T\right)\left(1-\frac{V^{2}}{c^{2}}\right)^{2}\left(1+4 \frac{V}{c} \cos \alpha\right) .
$$

Substituting the Eq. (16) into Eq. (3) we obtain:

$$
\begin{gathered}
\mathbf{F}=-\frac{2 \varepsilon \sigma}{3 c} \int_{0}^{\pi} \int_{0}^{2 \pi}\left(T_{0}^{4}+4 T_{0}^{3} \Delta T\right)\left(1-\frac{V^{2}}{c^{2}}\right) \times \\
\times\left(1+4 \frac{V}{c} \cos \alpha\right) d A \mathbf{n},
\end{gathered}
$$

or either,

$$
\begin{aligned}
\mathbf{F}= & \left(1-\frac{V^{2}}{c^{2}}\right)^{2} \times\left\{\left(-\frac{2 \varepsilon \sigma}{3 c}\right)\left(\int_{0}^{\pi} \int_{0}^{2 \pi}\left(T_{0}^{4}+4 T_{0}^{3} \Delta T\right) d A \mathbf{n}\right)+\right. \\
& \left.+\left(-\frac{2 \varepsilon \sigma}{3 c}\right)\left(4 \frac{V}{c}\right)\left(\int_{0}^{\pi} \int_{0}^{2 \rho}\left(T_{0}^{4}+4 T_{0}^{3} \Delta T\right)(\cos \alpha) d A \mathbf{n}\right)\right\},
\end{aligned}
$$

where:

$\cos \alpha=\mathbf{n} \cdot \mathbf{s}$. 
The unit vector normal to the surface element is $\mathbf{n}$ and the unit vector in the along-track direction is $\mathbf{s}=\left(s_{x} \mathbf{i}+s_{y} \mathbf{j}+s_{z} \mathbf{k}\right)$. In this case, the components of the unit vector $\mathbf{s}, s_{\mathrm{x}}, s_{\mathrm{y}}$ and $s_{\mathrm{z}}$ (Duha, 2000) are:

$$
\begin{gathered}
s_{x}=\cos n t \cos \omega t+\sin n t \sin \vartheta \sin \omega t, \\
s_{y}=-\cos n t \sin \omega t+\sin n t \sin \vartheta \cos \omega t, \\
s_{z}=\sin n t \cos \vartheta
\end{gathered}
$$

where $n$ is the mean body displacement, $\omega$ is the angular rotation frequency and $\vartheta$ is the spin axis inclination related to the orbital plane. These three quantities are the same for all points in the satellite surface, or either, they do not depend on the colatitude and longitude, $\theta$ and $\phi$, respectively.

Note that the first term on the right hand side of Eq. (18), $(-2 \varepsilon \sigma / 3 c)$.integral[1] is the thermal reemission force without relativistic effects given by $\mathrm{Eq}$. (6).The second term, $(-2 \varepsilon \sigma / 3 c)(4 v / c)$. integral[2], represents the force that comes out as a consequence of the Doppler effect and that must be added to the standard thermal re-emission force.

The integral[2] can be written as:

$$
4 \frac{V}{c}\left\{\left(T_{0}^{4}\right) \int_{0}^{\pi} \int_{0}^{2 \pi}(\cos \alpha) d A \mathbf{n}+\left(4 T_{0}^{3}\right) \int_{0}^{\pi} \int_{0}^{2 \pi} \Delta T(\cos \alpha) d A \mathbf{n}\right\}
$$

or either,

$$
4 \frac{V}{c} R^{2}\left\{\left(T_{0}^{4}\right)\left[\frac{4}{3} \pi\left(s_{x} \hat{\mathbf{i}}+s_{y} \hat{\mathbf{j}}+s_{z} \hat{\mathbf{k}}\right)\right]+\left(4 T_{0}^{3}\right) \times 0\right\} .
$$

Finally, we can write the Eq. (18) as follow:

$$
\begin{gathered}
\mathbf{F}=\left(1-\frac{V^{2}}{c^{2}}\right)^{2} n_{f}\left(A _ { 1 } \operatorname { s i n } ( v _ { 2 } t - \delta _ { 2 } ) \left[\cos \left(v_{1} t-\delta_{1}\right) \mathbf{i}+\right.\right. \\
\left.\left.+\sin \left(v_{1} t-\delta_{1}\right) \mathbf{j}\right]+A_{2} \cos \left(v_{2} t-\delta_{2}\right)\right\}+ \\
+\left(1-\frac{V^{2}}{c^{2}}\right)^{2}\left[\left(-\frac{32 E \sigma T_{0}^{4} \pi R^{2}}{9 c^{2}}\right) V\left(s_{x} \mathbf{i}+s_{y} \mathbf{j}+s_{z} \mathbf{k}\right)\right] .
\end{gathered}
$$

Now, using the following relations: $\varepsilon \sigma T_{0}^{4}=I_{0}$, $\pi R^{2}=A$, and $\mathbf{s}=s_{\mathrm{x}} \mathbf{i}+s_{\mathrm{y}} \mathbf{j}+s_{\mathrm{z}} \mathbf{k}$ (the unit vector pointing in the along-track direction) we can rewrite the equation above as:

$$
\begin{gathered}
\mathbf{F}=\left(1-\frac{V^{2}}{c^{2}}\right)^{2}\left\{n _ { f } \left\{A_{1} \sin \left(v_{2} t-\delta_{2}\right)\right.\right. \\
{\left[\cos \left(v_{1} t-\delta_{1}\right) \mathbf{i}+\sin \left(v_{1} t-\delta_{1}\right) \mathbf{j}\right]+} \\
\left.\left.+A_{2} \cos \left(v_{2} t-\delta_{2}\right) \mathbf{k}\right\}+\left(-\frac{32}{9}\right) \frac{I_{0} A}{c^{2}} \mathbf{V}\right\} .
\end{gathered}
$$

This is the approximated relativistic total reemission force acting on a spherical body with average surface temperature $T_{0}$. The first term is the standard re-emission force multiplied by the factor $\left(1-V^{2} / c^{2}\right)^{2}$ and the second term is similar to the standard Poynting-Robertson force (Guess, 1962; Wyatt \& Whipple, 1950) but, multiplied by the factor $\left(1-V^{2} /\right.$ $\left.c^{2}\right)^{2}$. However, when we use the approximate expression for the temperature we lose the information about the PR such as force and its relation with body rotation and temperature variations at the surface. But, this approximated expression is very important to the aim of this work, because it shows clearly the connection of this new force with the PR effect that can be obtained from the thermal re-emission model presented here. One needs only to assume that $\Delta T=$ 0 , and $V \ll<c$. In fact, for the great majority of cases $\left(1-V^{2} / c^{2}\right)^{2} \approx 1$.

It is interesting to remark, also, that the PR effect requires photon emission or re-emission processes. Whatever, the PR effect will always depend on heating processes. In fact, the PR effect is part of the overall thermal effects and do not exist without them.

Another result is that the relativistic thermal reemission effect (thermal effect plus PR) will disappear when $V=c$. The classical PR effect does not predict this result and fails at another points: if the temperature distribution at the surface is anisotropic and the body rotates the PR effect could be bigger or smaller than the classical predictions.

Poynting-Robertson like effects depend on the rotation angular frequency. This dependence cannot be seen here because we have used the approximated expression given by Eq. (15) for our relativistic model, but it should appear in a complete relativistic thermal model (without approximations). 


\section{CONCLUSION}

The work presented here has shown the development of a thermal model where the temperature $T$ of each surface point is corrected in order to take into account the Doppler effect. The direct relation between photon frequency and temperature provides a new temperature distribution for the body's surface. This new temperature distribution, when applied to the thermal model, leads to the so called relativistic thermal re-emission force, that is the sum of the standard thermal re-emission force with a PR like force due to the relativistic correction of the anisotropic temperature distribution at the surface of the emitter. Therefore, the relativistic thermal re-emission force encompass the standard thermal re-emission force (without Doppler considerations) plus a new force that comes out due to the introduction of the Doppler effect in the standard thermal model. This new force is similar to the Poynting-Robertson force, already known in the literature, but it is a force that appears as a consequence of the application of the Doppler effect to an anisotropic temperature distribution, whereas the standard PR force assumes that the temperature distribution is isotropic. Finally, the main conclusion of this work is that most of the several disturbing forces can be unified, leading to a new and simple view, able to make easier the understanding of the overall physics involved and to provide more accurate and complete equations for the non-gravitational disturbing forces on orbits.

\section{REFERENCES}

Afonso, G.B. \& Foryta, D.W., 1989. An anisothermical emission model for small bodies, in Orbital Dynamics of Natural and Artificial Objects (editado por R. Vieira-Martins, D. Lazarro and W. Sessin), pp. 73-83. Observatório Nacional, Rio de Janeiro.

Duha, J., 1996. Modelling and Applications of the Summer-Winter Effect, M.Sc. Thesys, UFPR.

Duha, J., 2000. Modelling of the Thermal Reemission Effects on Artificial Satellites: LAGEOS and GPS, Phd. Thesys, UFPR.

Duha, J. \& Afonso, G. B., 1999. Thermal force effects on satellites. Brazilian J. Geophys., 17(2,3): 163-174.

Eisberg, R.\& Resnick, R., 1988. Quantum Physics of Atoms, Molecules, Solids, Nuclei and Particles. Editora Campus.

Guess, A. W., 1962. Poynting-Robertson effect for a spherical source of radiation. The Astrophysical J., 135: 855-866.

Landau, L. \& Lifchitz, E., 1966. Théorie du Champ, Editions MIR.

Rubincam, D.P., 1990. Drag on the LAGEOS satellite. J. Geophys. Res., 95: 4881-4886.

Rubincam, D.P., Currie, D.G.; Robbins, J.W., 1997. LAGEOS I once-per-revolution force due to solar heating. J. Geophys. Res., 102: 585-590.

Srikanth, R., 1999. Physical interpretation of the Poynting-Robertson effect. Icarus, 140: 231-234.

Wyatt, S. P. Jr. \& Whipple, F. L., 1950. The Poynting-Robertson effect on meteor orbits. The Astrophysical J., 111: 134-134.

\section{MODELORELATIVÍSTICODE RE-EMISSÃO TÉRMICA}

Inicialmente, apresenta-se de forma resumida o modelo de re-emissão térmica unificado à partir do qual se obtêm a força de re-emissão térmica total: força noite-dia (diurnal effect) mais força inverno-verão (seasonal effect). A força de re-emissão térmica resultante é calculada, basicamente, à partir do conhecimento da distribuição de temperaturas $T$ na superfície do corpo aquecido. A temperatura de cada ponto determina, por sua vez, a energia dos fótons emitidos, ou seja, sua freqüência. Quanto maior a freqüência dos fótons emitidos, maior a perda de momento linear associada à esse ponto. Para calcular a força resultante sobre o corpo, é necessário somar a contribuição de cada um dos pontos na superfície do corpo emissor. É essa soma vetorial de momento linear que irá determinar o módulo, a direção e o sentido da força de re-emissão térmica. No entanto, a perda de momento associada à cada ponto está diretamente ligada à freqüência dos 
fótons emitidos cujo valor depende não apenas da temperatura do ponto emissor, mas também da velocidade do mesmo em relação à um referencial inercial. Portanto, se o corpo que está emitindo ou reemitindo energia se encontra em movimento (rotação, translação, etc.) haverá um aumento na freqüência dos fótons emitidos na direção do movimento e um decréscimo na direção contrária. Essa variação de freqüências devida ao movimento do corpo é conhecida como efeito Doppler e ela altera o módulo, direção e sentido da força de re-emissão térmica. A força de re-emissão térmica relativística é composta, então, pela força de re-emissão térmica padrão (sem considerações Doppler) mais uma força nova, que surge devido à introdução do efeito Doppler no modelo. Esta força nova é semelhante à força PoyntingRobertson (PR), já conhecida na literatura, porém, é uma força que surge da aplicação do efeito Doppler à uma distribuição anisotrópica de temperaturas na superfície do corpo, enquanto, que a força PR assume que o corpo aquecido possui a mesma temperatura em todos os pontos da superfície. Neste trabalho é desenvolvido um modelo no qual a temperatura $T$ de cada ponto da superfície é corrigida devida ao efeito Doppler, ou seja, como a freqüência dos fótons está diretamente relacionada à temperatura, é possível obter uma nova distribuição de temperaturas. Essa distribuição de temperaturas corrigida quando aplicada ao modelo térmico conduz à assim chamada força de re-emissão térmica relativística, que nada mais é senão a soma da força de re-emissão padrão com uma força do tipo PR devida à correção relativística da distribuição anisotrópica de temperaturas na superfície do corpo emissor

\section{NOTE ABOUT THE AUTHORS}

\section{Jânia Duha}

Is a professor in the Department of Physics at the Universidade Federal do Paraná (UFPR), Curitiba, Brazil, where she has been teaching since 2000. She obtained her MSc. degree in Physics with the thesis Modelling and Aplication of the Summer-Winter Effect and Dr. Sc. degree in Geodesy with the thesis Modeling of the Thermal Re-emission Effects on Artificial Satellites: $L A G E O S$ and GPS. Since then, Dr. Duha has been working extensively with the modelling and aplication of thermal re-emission forces on artificial satellites. Her research interests are related also with Dynamical Evolution of Natural Satellites and Asteroid Fragments.

\section{Germano Bruno Afonso}

Is a full professor in the Department of Physics at the Universidade Federal do Paraná (UFPR), Curitiba, Brazil, where he has been teaching since 1973. He has a degree in Physics and a MSc. in Geodesy from the Universidade Federal do Paraná and a Dr. Sc. in Astronomy from the
Université Pierre et Marie Curie, Paris, France. Dr. Afonso has worked extensively with Non-Gravitational Forces Modelling Effects on Artificial Satellites and Asteroid Fragments Orbits. His research interests are related also with Dynamical Evolution of Earth-Moon System and with Brazilian Archaeoastronomy.

\section{Luiz Danilo Damasceno Ferreira}

Is a professor in the Department of Geomatics at the Universidade Federal do Paraná (UFPR), Curitiba, Brazil. He has a degree in Physics and a MSc. in Geodesy from UFPR and a Dr. Sc. in Space Mechanics from the National Institute for Space Research (INPE), São José dos Campos, Brazil, where he has worked in Attitude Control of the first and second Brazilian Data Collecting Satellites. Nowadays, he is working in Perturbing Forces caused by Solar Radiation Pressure on the GPS satellites and in Structure Deformation Monitoring of geodetic network using GPS. 


\title{
Universidade Federal do Paraná Setor de Ciências da Terra
}

- Departamento de Geomática

- Pós Graduação em Ciências Geodésicas

- Curso de Engenharia Cartográfica

- Curso de Especialização em Geotecnologias

\begin{abstract}
O Departamento de Geomática (DGEOM) está vinculado ao Setor de Ciências da Terra, e é responsável pelo Curso de Engenharia Cartográfica e pelo Curso de Pós Graduação em Ciências Geodésicas (Mestrado e Doutorado). Oferta também Disciplinas aos Cursos de Engenharia Civil, Engenharia Agronômica, Engenharia Florestal, Arquitetura e Urbanismo, Matemática, Geologia, Geografia e Pós Graduação em Engenharia Florestal, dentro de suas especialidades de levantamentos, processamento, análise, representação e gerenciamento de dados espaciais. O Departamento de Geomática conta com laboratórios de Fotogrametria e Sensoriamento Remoto, Cartografia, Geodésia Espacial, Sistemas de Informação Geográfica, Instrumentação Geodésica e Estação de Marés Terrestres, os quais apoiam o ensino e a pesquisa ao nível de graduação e pós graduação. Na forma de intercâmbio ou assessoria, são mantidos convênios nacionais e internacionais com universidades, empresas e instituições governamentais que atuam ou utilizam conhecimentos da área. O Departamento também oferta à comunidade cursos de extensão em suas áreas de conhecimento.
\end{abstract}

\section{Universidade Federal do Paraná \\ Departamento de Geologia}

\section{Laboratório de Pesquisa em Geofísica Aplicada áreas de atuação}

- exploração mineral

- exploração de hidrocarbonetos

- exploração de águas subterrâneas

-estudos geotécnicos

-estudos geoambientais

-integração de dados exploratórios multifonte 